\title{
Size-dependent allocation of biomass to ancillary versus flowers of the inflorescences of the epiphyte Tillandsia stricta Soland (Bromeliaceae)
}

\author{
André Mantovani ${ }^{1,3}$ and Ricardo Rios Iglesias ${ }^{2}$
}

Received: November 5, 2007. Accepted: May 26, 2008

\begin{abstract}
RESUMO - (Influência do tamanho do corpo na alocação de biomassa em estruturas de suporte e flores da bromélia epífita Tillandsia stricta Soland. (Bromeliaceae)). A quantidade de recursos investidos na reprodução sexuada em geral é positivamente correlacionada à quantidade dos mesmos recursos investidos no corpo vegetativo da planta; porém nem sempre de forma proporcional. A proporção dos recursos da planta alocados na reprodução sexuada pode aumentar, diminuir ou se manter constante ao longo do aumento do tamanho do corpo vegetativo. Embora compreendendo milhares de espécies, as epífitas são pouco conhecidas quanto ao padrão de alocação de recursos na reprodução sexuada. Neste estudo é descrita a variação da alocação de recursos na reprodução sexuada da bromélia epífita Tillandsia stricta Soland conforme diferentes tamanhos de corpo vegetativo. O objetivo é avaliar como tal alocação se dá para a inflorescência total à medida que seu corpo vegetativo cresce, bem como quantificar a participação das estruturas de suporte da inflorescência nesta alocação. Com o aumento do corpo vegetativo, a alocação de biomassa na inflorescência como um todo reduziu de $37 \%$ para $12 \%$. Entretanto, especificamente para as estruturas de suporte e flores que constituem tal inflorescência, a redução na alocação de biomassa foi de 30\% para 9\%, nas estruturas de suporte, e de 10\% para 3\% nas flores. Tanto a área foliar total quanto a área por folha, usadas aqui como indicadoras de forrageamento, também aumentaram com o aumento do tamanho do corpo vegetativo. Tais resultados são discutidos quanto à capacidade de T. stricta de se reproduzir sexuadamente sob as condições heterogêneas da copa das árvores.
\end{abstract}

Palavras-chave: alocação, alometria, Bromeliaceae, estruturas reprodutivas de suporte, Tillandsia

ABSTRACT - (Size-dependent allocation of biomass to ancillary versus flowers of the inflorescences of the epiphyte Tillandsia stricta
Soland (Bromeliaceae)). The amount of resources invested in reproduction is closely correlated to plant size. However, the increase in
reproductive investment is not always proportional to the increase in vegetative growth, as the proportion of plant resources allocated
to reproduction can increase, decrease or be maintained along different plant sizes. Although comprising thousand of species, epiphytes
are poorly studied in relation to reproductive allocation (RA). We describe the variation in the RA of the epiphytic bromeliad Tillandsia
stricta Soland with increasing plant sizes. Our goal is not only to evaluate the RA of the whole inflorescence but also quantify the
contribution of ancillary structures in the final RA of this plant species. With increasing sizes of T. stricta the reproductive allocation of
biomass to the whole inflorescence decreased significantly along plant sizes from $37 \%$ to $12 \%$. Reproductive allocation to ancillary and
to flowers decreased respectively from $30 \%$ to $9 \%$ and $10 \%$ to $3 \%$. As leaves are the main source of water and nutrients absorption in
atmospheric Tillandsia, the total leaf area and area per leaf were used as indicators of foraging capacity, that also increased with plant
size. We discuss these results with respect to the capacity of T. stricta to reproduce in the heterogeneous environment of the canopies.

Key words: allocation, allometry, ancillary structures, Bromeliaceae, Tillandsia

\section{Introduction}

Reproductive allocation (RA) is defined as the proportion of resources (energy, biomass and nutrients) invested in reproductive organs such as inflorescence, fruits or seeds (Abrahamson \& Caswell 1982; Bazzaz et al. 1987). At the intraspecific level, the amount of resource invested in reproduction is closely correlated to plant size and biomass, i.e. bigger/heavier plants invest more to flowering than smaller plants (Aarseen \& Taylor 1992). However, the increase in reproductive investment is not always proportional to the increase in vegetative growth. The proportion of plant resources allocated to reproduction can increase, decrease or be maintained along increasing plant sizes (Bazzaz et al. 1987).

The variation in reproductive allocation (RA) with plant sizes is of great ecological importance (Soule \& Werner 1981). As the functions of defense, growth and storage compete with reproduction for resources (Bazzaz et al. 1987), RA is influenced by stronger functional demands for defense and/or vegetative growth according to the environment. This variation in RA helps

\footnotetext{
1 Instituto de Pesquisa Jardim Botânico do Rio de Janeiro, Rua Pacheco Leão 915, 22460-030 Jardim Botânico, Rio de Janeiro, RJ, Brasil

2 Universidade Federal do Rio de Janeiro, Instituto de Biologia, Laboratório de Ecologia de Comunidades, Departamento de Ecologia, 21941-590, Ilha do Fundão, Rio de Janeiro, RJ, Brasil (rir@biologia.ufrj.br)

3 Corresponding Author: andre@jbrj.gov.br
} 
to explain resource allocation patterns not only in an ecological but also in an evolutionary basis (Cody 1966; Harper 1967; Bazzaz 1996).

Following Bazzaz \& Reekie (1985), one of the major problems in quantifying RA is the definition of which structures should be considered part of the RA. In relation to reproductive structures, they can be divided in obvious and ancillary structures. Flowers, fruits and seeds are obvious reproductive structures. Ancillary structures for support such as bracts and scape are not, but should be considered as part of RA because participation in reproduction and the allocation to these functions could be essential in reproduction, and should therefore be considered (Bazzaz et al. 1987).

Although comprising thousand of species (Benzing 1990), epiphytes are poorly studied in relation to RA. The available information on epiphytes deals with infruitescences of one bromeliad and two orchids (Benzing 1990; Zotz 1999). In relation to size dependence, only Zotz (2000) evaluated the variation of RA of an epiphytic plant, Dimerandra emarginata (G. Meyer) Hoehne according to distinct sizes.

In this paper, we describe the variation in the RA of Tillandsia stricta among several ramet sizes. Our goal is not only to evaluate a possible size dependence of the RA but also to quantify the contribution of ancillary structures in the final RA of this plant species.

\section{Material and methods}

Tillandsia stricta Soland is a clonal bromeliad, presenting interconected ramets (Benzing 1990). Each ramet flowers just one time, producing monoecious flowers. In June of 2001, thirty different flowering genets of $T$. stricta, presenting just one ramet with a mature inflorescence, were collected in the private property Reserva Botânica das Águas Claras (22 $30^{\circ} \mathrm{S}$, $42^{\circ} 30^{\prime} \mathrm{W}$ ), located in Silva Jardim county, Rio de Janeiro State. The reserve is in the Atlantic rainforest domain, and belongs to the low-montane type of vegetation. Annual rainfall is around $2200 \mathrm{~mm}$, with a mid-year reduction of $80 \%$. Average monthly temperature varies from $19{ }^{\circ} \mathrm{C}$ to $25^{\circ} \mathrm{C}$ (Mantovani 1999a; b). In order to detect size dependence on reproductive allocation, ramets were collected according to visually distinct sizes. As differences in the environmental conditions of distinct host species and sites (Freiberg 1997) can influence size effect on reproductive allocation (Zotz 2000), all plants were collected between 2 to $5 \mathrm{~m}$ of the main trunks of individuals of Clittoria fairchildiana Howard (Leguminosae) located 4 to $8 \mathrm{~m}$ apart. The plants were removed from the host and brought to the laboratory in plastic bags. In the laboratory, each ramet was separated from its respective genet and analyzed as follows. Each ramet was gently defoliated, leaf by leaf; all leaves were counted and their maximum width and length measured with a precision ruler $(1 \mathrm{~mm})$. This was done in order to calculate each leaf area, considered here as an isosceles triangle (Reinert \& Meirelles 1983). The sum of leaf areas (adaxial plus abaxial) for each ramet was denominated total leaf area per ramet, and calculated as:

Total leaf area $=(($ base $\times$ length $) / 2) \times 2 \ldots$

For atmospheric bromeliads from the genus Tillandsia, the main organ for photosynthesis and nutrient capture is the leaf (Benzing 1973). Roots are very short and have minor contributions to these functions, with importance apparently limited to fixation on hosts. In this sense, the total leaf area per ramet was considered here as an index of foraging capacity (Ray 1992).

The rhyzome and inflorescence scape, which remain contiguous after defoliation, were separated with a razor blade. Both structures were easily morphologically distinguished by the longer internodes of the inflorescence. Each inflorescence was then separated from the rhyzome, cutting it below the first long internode of the scape.

The parts of the inflorescence, i.e., scape, bracts and flowers were then separated by hand and stored in glass containers. Leaves and inflorescence parts were dried until constant weight at $50{ }^{\circ} \mathrm{C}$, and then weighed on a $0.001 \mathrm{~g}$ precision balance. The ramet dry mass (RDM) was quantified by the sum of rhyzome plus total leaf dry mass. The weight of RDM was considered here as an indicator of ramet size (Zotz 2000). The investment in reproduction was divided into two morphological components, "ancillary" and "flowers". The ancillary component was determined as the dry mass of scape and bracts. Floral structures were considered here as the collection of sepals, petals, male and female parts. Reproductive allocation (RA) of dry mass was determined for the whole inflorescence (RAI), and separately for "ancilary" (RAA) and "flowers" (RAF). There are several mathematical formulas to calculate RA (Bazzaz \& Reekie 1985). In order to standardize results for epiphytes (Zotz 2000), the RE1 model (sensu Bazzaz 1996) was followed:

RAI $(\%)=($ inflorescence dry mass $* 100) /$ ramet dry mass ........2)

RAA $(\%)=($ scape + bracts dry mass $* 100) /$ ramet dry mass .... (3)

$\operatorname{RAF}(\%)=($ flower dry mass $* 100) /$ ramet dry mass

The influence of plant size in the RA of T. stricta was evaluated by regression analysis considering the plant size as the independent variable. Previous tests confirmed normal distribution and homogeneity of variance of the 
132 Mantovani \& Iglesias: Size-dependent allocation of biomass to ancillary versus flowers of the inflorescences...

data. The significance of regression indices were calculated by ANOVA (Zar 1996). The regression curves were compared with linear and polynomial models in order to detect stabilization of investments in reproductive structures at greater plant sizes. The stabilization was confirmed by the occurrence of significant $\mathrm{bx}^{2}$ constants in polynomial models (Aarseen \& Taylor 1992). In order to compare angular coefficients from linear regression lines, a t-test was applied, following Zar (1996). Softwares SYSTAT and Sigmastat were used for the statistical analyses.

\section{Results}

Reproductive investment increased with increase in plant size (Fig. 1-6). Ramet and inflorescence dry masses were highly correlated $\left(\mathrm{R}^{2}=0.81 ; \mathrm{F}=122.4\right.$; $\mathrm{p}<0.0001$ ) (Fig. 1), however, reproductive investment was different when inflorescences were analyzed in the isolated components, "ancillary" and "flowers". Although "ancillary" significantly increased with ramet size $\left(\mathrm{R}^{2}=0.81 ; \mathrm{F}=120.6 ; \mathrm{p}<0.0001\right)$, as "flowers" $\left(\mathrm{R}^{2}=0.75 ; \mathrm{F}=85.8 ; \mathrm{p}<0.0001\right)$, the rates of increase were distinct, indicated by the angular coefficients (Fig. 2). The angular coefficient for "ancillary" $(b=0.098)$ was significantly higher $(t=12,07 ; d f=56$; $\mathrm{P}<0.001)$ from the coefficient of "flowers" $(\mathrm{b}=0.038)$. There was greater investment in "ancillary" than on "flowers" along the increase in ramet dry mass. For all ramet sizes and weights, the mean investments of dry mass in ancillary, flowers and in the whole inflorescence were respectively $0.048 \pm 0.02 \mathrm{~g} ; 0.128 \pm 0.06 \mathrm{~g}$ and $0.17 \pm 0.09 \mathrm{~g}$.

Although the amount of dry mass invested in reproduction increased with ramet dry mass, the individual investments were not proportional. Along the ramet sizes of studied plants, the inflorescence dry mass varied by a factor of 11 ( 0.037 to $0.423 \mathrm{~g})$ while ramet dry mass varied by a factor of 25 ( 0.108 to $2.721 \mathrm{~g})$. As a consequence the Reproductive Allocation (RA), calculated on a ramet dry mass basis, decreased significantly with plant sizes $(\mathrm{p}<0.0005)$ from 37 to $12 \%$ (Fig. 3). Dividing the allocation in the components Reproductive Allocation into Ancillary (RAA) structures and Flowers (RAF) revealed the same decreasing pattern with plant size $(\mathrm{p}<0.0004)$ (Fig. 4). While ancillary dry mass varied by a factor of 13 ( 0.023 to $0.306 \mathrm{~g})$ and flowers varied by a factor of $10(0.011$ to $0.119 \mathrm{~g})$, both rates were much smaller than the increase of 25 times in the ramet dry mass. RAA and RAF decreased respectively from $30 \%$ to $9 \%$ and $10 \%$ to $3 \%$.

The foraging capacity also increased with plant size (Fig. 5-6). The total leaf area was significantly correlated with ramet dry mass $\left(\mathrm{R}^{2}=0.91 ; \mathrm{F}=292.8 ; \mathrm{P}<0.0001\right)$. This result was expected as the number of leaves was also correlated with ramet dry mass $(\mathrm{P}<0.0001)$ (Fig. 6). However, not only the number of leaves but also the area per leaf increased. If the area per leaf had been constant, the increase in total leaf area per ramet would depend only on the increase of leaf number. In this sense, the ratio leaf area/leaf number would be constant and equal 1 . However, this ratio increased with total ramet dry mass (Fig. 6) $\left(\mathrm{R}^{2}=0.70 ; \mathrm{F}=67.15 ; \mathrm{P}<0.0001\right)$. The polynomial regression between leaf number versus ramet dry mass was significant $\left(\mathrm{R}^{2}=0.77 ; \mathrm{F}=45.883\right.$; $\mathrm{P}<0.0001$; leaf number $=15.4+37.5 \mathrm{RDM}-6.9 \mathrm{RDM}^{2}$ ) and confirmed by a significant and negative value for $\mathrm{bx}^{2}(\mathrm{t}=-2.52 ; \mathrm{P}=0.018)$, indicating a stabilization of the leaf number with larger plant size. However this did not occur for the regression between the ratio leaf area/ leaf number versus ramet dry mass $(\mathrm{P}=0.231)$, indicating that among all plant sizes leaf area and therefore, the foraging capacity, increased.

The regression analyses between plant size and investment and allocation of biomass to whole inflorescence, ancillary and flowers were significant for linear regressions. However besides the regressions between leaf number and area versus ramet dry mass cited above, few of the polynomial relations presented stabilization at larger ramet sizes, as confirmed by a significant $\mathrm{bx}^{2}$. The regressions between ramet dry mass ( $\mathrm{RDM})$ versus $\mathrm{RAI}(\mathrm{b}=5.13 ; \mathrm{t}=2.834 ; \mathrm{P}=0.009 ; \mathrm{RAI}=$ $\left.34.0+20.2 \mathrm{RDM}+5.1 \mathrm{RDM}^{2}\right) ; \mathrm{RAA}(\mathrm{b}=3.25 ; \mathrm{t}=2.490$; $\mathrm{P}=0.019 ; \mathrm{RAA}=23.9+13.2 \mathrm{RDM}+3.2 \mathrm{RDM}^{2}$ ) and RAF $(b=1.88 ; \mathrm{t}=2.653 ; \mathrm{P}=0.013 ; \mathrm{RAF}=10.9+6.9$ $\mathrm{RDM}+1.8 \mathrm{RDM}^{2}$ ) presented stabilization at ramet dry masses higher than $1 \mathrm{~g}$.

\section{Discussion}

Terrestrial plants have been intensively studied in relation to the variation of reproductive allocation (RA). In general, the RA varies from $12-15 \%$ of the vegetative dry mass, in perennials, to $20-30 \%$ in annuals (Evenson 1983; Hancock \& Pritts 1987). However, few studies analyzed the patterns of RA for plants occurring in tree canopies (Benzing 1990). The available data reveal that $4-25 \%$ of biomass, $7-33 \%$ of nitrogen and $12-58 \%$ of phosphorous is invested in maturing fruits of three epiphytic orchids and one epiphytic bromeliad (Benzing \& Ott 1981; Zotz 1999; 2000). These values can exceed the RA of terrestrial perennial plants and approximate the RA of annual ones. The smallest ramet of $T$. stricta allocated more than $30 \%$ of biomass to the inflorescence indicating that a high allocation pattern can occur for this epiphyte. 
Most studies on plant resource allocation to reproduction use only obvious reproductive structures, regardless of ancillary structures, in order to calculate RA (Bazzaz 1996; Zotz 2000). However, Thompson \& Stewart (1981) suggested that all structures not present on vegetative plants should be considered reproductive since these structures are part of the effort involved in reproduction. Bazzaz \& Reekie (1985) state that the proportion of resources invested to ancillary structures can be substantial. Results reported here show that the amount of biomass allocated to ancillary structures is three times higher than biomass allocated to flowers in $T$. stricta inflorescences. Also, the proportion of allocations to
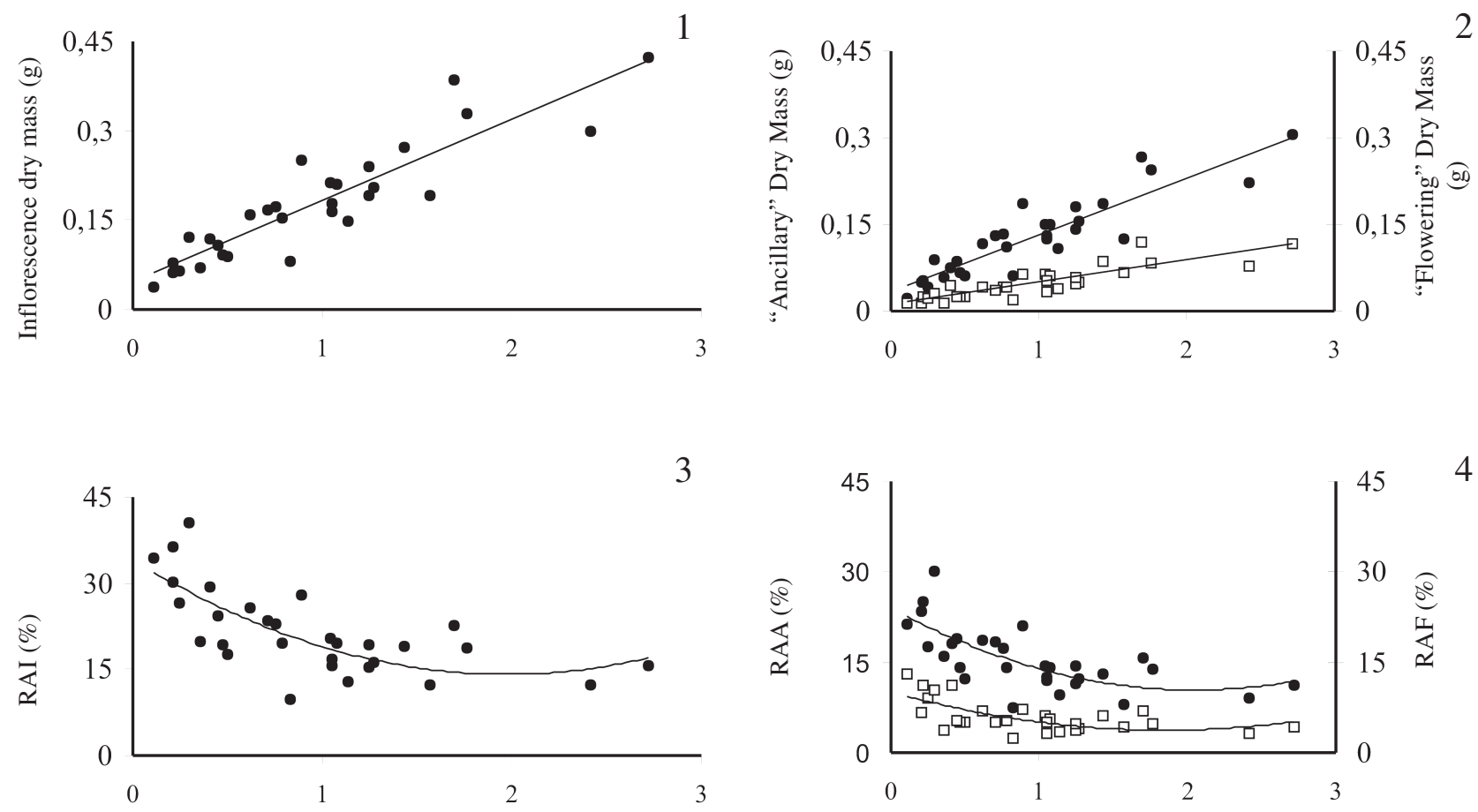

5
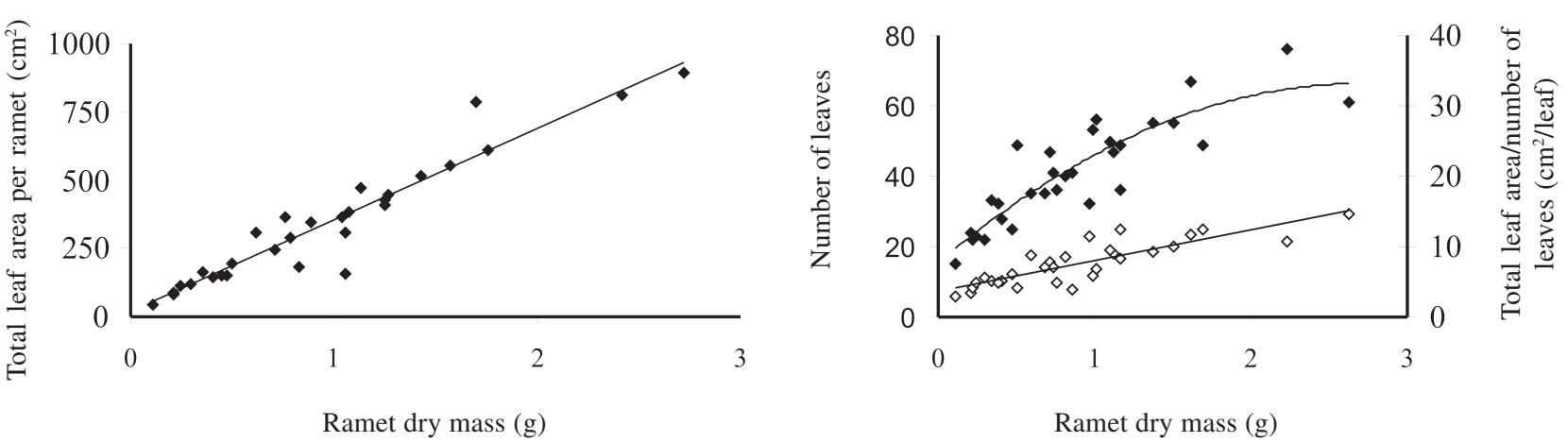

Figures $1-6$. Size dependency in investment $(1 ; 2)$ and allocation $(3 ; 4)$ of dry mass to reproduction, and on foraging capacity $(5 ; 6)$ of Tillandsia stricta Soland (Bromeliaceae). The weight of ramet dry mass was considered here as an indicator of ramet size. 1. Note significant positive regression $(\mathrm{p}<0.0001)$ between ramet size and investment of dry mass in inflorescence. 2. Dividing inflorescence in "ancillary" $(\bullet)$ and "flowering" ( $\square)$. The investment of dry mass in each component increases with ramet size $(\mathrm{p}<0.0001)$, but the rate of increase is higher for "ancillary" in comparison to "flowers" component (see text for details). 3. Regression between ramet size and reproductive allocation of dry mass to inflorescence (RAI) of T. stricta. Note the decrease of RAI from around $37 \%$ to $12 \%$ in bigger ramets. Note stabilization of RAI beginning around $1 \mathrm{~g}$ of ramet dry mass. 4. Regression between ramet size and reproductive allocation of dry mass to "ancillary" (RAA) $(\bullet)$ and "flowers" (RAF) ( $\square$ ) from inflorescences of $T$. stricta. Note stabilization of RAA and RAF beginning around $1 \mathrm{~g}$ of ramet dry mass. 5. Foraging capacity. Note the significant positive regression $(\mathrm{P}<0.0001)$ between ramet dry mass and total leaf area per ramet. 6 . Foraging capacity. Note the significant positive between ramet dry mass, number of leaves $(\diamond)$ and area per leaf $(\diamond)(\mathrm{p}<0.0001)$. 
ancillary structures and flowers was not constant over distinct plant sizes. In this sense biomass allocation to flowers was not a good indicator of total biomass allocation to reproduction in T. stricta.

Bazzaz et al. (1987) state that resource (water and/or nutrient) availability influences RA. On an intraspecific basis, plants at richer sites usually grow and invest more biomass to flowering than plants at oligotrophic sites. Humid/ rich or dry/oligotrophic sites are found along the heterogenous epiphytic environments (Longino 1986; Putz \& Holbrook 1989; Benzing 1990; Mantovani 2001) and could help explain the RA variation found here for T. stricta. However, as partitioning of resources in plants should lead to a trade-off between reproduction and vegetative growth (Bazzaz 1997), this result should also be related to the vegetative dry mass of $T$. stricta. The majority of the vegetative dry mass of $T$. stricta is represented by the leaves.

In atmospheric bromeliads, leaves comprise the main organ for water and nutrient absorption, while roots are reduced and mainly used for fixation on the host (Benzing 1990; Benzing \& Ott 1981). The capacity for nutrient capture realized by bromeliad leaves is only possible due to the presence of specialized trichomes (Benzing 1976), which in T. stricta covers almost 100\% of the leaf area. Making photosynthesis and capturing resource, the leaves of $T$. stricta could be considered the main foraging site in this species. Results reported here indicate that with increasing ramet sizes of T. stricta, not only more leaves, but also larger ones, were produced.

Benzing \& Ott (1981) studied the phenomenon of vegetative reduction in orchids and bromeliads. While in orchids body reduction occurred in the leaves, in bromeliads it occurred in the root system. In some orchids photosynthesis and resource absorption are realized by the roots (Cockburn et al. 1985), while for atmospheric bromeliads it is mainly realized by the leaves. Zotz (2000) reports that the absolute root mass of the orchid D. emarginata increased 10-fold from the smallest flowering plant ( $4 \mathrm{~cm}$ tall plants) to tallest ones (33 cm tall plants). This increase in mass represented a total root length from 200 to $>1200 \mathrm{~cm}$. The author proposed that this increase in total root length of $D$. emarginata, widening the area covered by the root system, increased the probability of accessing more nutrient-rich patches in the epiphytic habitat. The same pattern was detected here for T. stricta, but for the leaf organ. The total leaf area per plant varied from $43 \mathrm{~cm}^{2}$ in the smallest ramet $(0,1 \mathrm{~g})$ to $893 \mathrm{~cm}^{2}$ in the biggest ramet $(2,7 \mathrm{~g})$, increasing the foraging capacity as plant sizes increases.

We propose that $T$. stricta can be highly efficient to deal with the heterogeneous nutritional conditions of forest canopies. First, the availability of resources do not only induce the vegetative growth per se. The new and larger leaves produced can acquire more resources, making the plant grows further (see "compound interest analogy" in Reekie \& Bazzaz 1987). This is highly important as atmospheric bromeliads rely only on leaves for foraging. Secondly, there is size dependency of reproductive allocation in the atmospheric bromeliad $T$. stricta. Size dependency for reproductive traits could reveal functional responses to resource availability (Bonser \& Aarseen 2003). This size modulation could improve plant fecundity and fitness even at population level, considering the patchiness of resource availability of the epiphytic environment (Zotz 2000).

In conclusion, besides the novel anatomical and photosynthetical adaptations to survive in the epiphytic environment, T. stricta can also be efficient in the allocation of biomass, allowing the subject plants to survive and reproduce throughout the heterogeneous environment of the canopies.

\section{References}

Aarsseen, L.W. \& Taylor, D.R. 1992. Fecundity allocation in herbaceous plants. Oikos 65: 225-232.

Abrahamson, W. \& Caswell, H. 1982. On the comparative allocation of biomass, energy and nutrientes in plants. Ecology 63: 982-991.

Bazzaz, F.A. \& Reekie, E.G. 1985. The meaning and measurement of reproductive effort in plants. Pp. 377-387. In: J.L. Harper \& J. White (eds.). Studies on Plant Demography: a Festschrift for John L. Harper. London, Academic Press.

Bazzaz, F.A. 1996. Plants in changing environments. Cambridge, Cambridge University Press.

Bazzaz, F.A. 1997. Allocation of resources in plants: state of the science and critical questions. Pp. 1-37. In: A. Bazzaz; Fakhri \& J. Grace (eds.). Plant resource allocation. London, Academic Press.

Bazzaz, F.A.; Chiariello, N.R.; Coley, P.D. \& Pitelka, L.F. 1987. Allocating resources to reproduction and defense. BioScience 37: 58-67.

Benzing, D.H. 1973. Mineral nutrition and related phenomena in Bromeliaceae and Orchidaceae. Quarterly Review of Biology 48: 278-290.

Benzing, D.H. 1976. Bromeliad trichomes: structure, function and ecological significance. Selbyana 1: 330-348.

Benzing, D.H. 1990. Vascular epiphytes: General Biology and related biota. New York, Cambridge University Press.

Benzing, D.H. \& Ott, D.W. 1981. Vegetative reduction in epiphytic Bromeliaceae and Orchidaceae, its origin and significance. Biotropica 13: 131-140. 
Bonser, S.P. \& Aarssen, L.W. 2003. Allometry and development in herbaceous plants, functional responses of meristem allocation to light and nutrient availability. American Journal of Botany 90: 404-412

Cockburn W.; Goh, C.J. \& Avadhani, P.N. 1985. Photosynthetic carbon assimilation in a shootless orchid Chiloschista usneoides (Don) Ldl. Plant Physiology 77: 83-86.

Cody, M.L. 1966. A general theory of clutch size. Evolution 20: 174-184.

Evenson, W.E. 1983. Experimental studies of reproductive energy allocation in plants. Pp. 249-274. In: C.E. Jones \& R.J. Little (eds.). Handbook of experimental pollination biology. New York, Van Nostrand Reinhold.

Freiberg, M. 1997. Spatial and temporal pattern of temperature and humidity of a tropical premonatane Rain Forest tree in Costa Rica. Selbyana 18: 77-84.

Hancock, J.F. \& Pritts, M.P. 1987. Does reproductive effort vary across different life forms and seral environments? A review of the literature. Bulletin of the Torrey Botanical Club 114: 53-59.

Harper, J.L. 1967. A Darwinian approach to plant ecology. Journal of Ecology 55: 247-270.

Longino, J.T. 1986. Ants provide substrates for epiphytes. Selbyana 9: 100-103.

Mantovani, A. 1999a. Leaf morpho-physiology and distribution of epiphytic aroids along a vertical gradient in a Brazilian Rain Forest. Selbyana 20: 241-249.

Mantovani, A. 1999b. A method to improve leaf succulence quantification. Brazilian Archives of Biology and Technology 42: 9-14.
Mantovani, A. 2001. Leaf orientation in hemiepiphytic and holoepiphytic aroids, significance to the leaf water and temperature balance. Leandra 15: 91-103.

Putz, F.E. \& Holbrook, N.M. 1989. Strangler fig rooting habitats and nutrient relations in the Llanos of Venezuela. American Journal of Botany 76: 781-788.

Ray, T.S. 1992. Foraging behaviour in tropical herbaceous climbers (Araceae). Journal of Ecology 80: 189-203.

Reekie, E.G. \& Bazzaz F.A. 1987. Reproductive Effort in Plants. 2. Does Carbon Reflect he Allocation of Other Resources? The American Naturalist 129: 897-906.

Reinert, F. \& Meirelles, S.T. 1993. Water acquisition strategies shifts in the heterophyllous saxicolous bromeliads Vriesia geniculata (Wawra) Wawra. Selbyana 14: 80-88.

Soule, J.D. \& Werner, P.A. 1981. Patterns of resource allocation in plants, with special reference to Potentilla recta $\mathrm{L}$. Bulletin of the Torrey Botanical Club 108: 311-319.

Thompson, K. \& Stewart, A.J.A. 1981. The measurement and meaning of reproductive effort in plants. American Naturalist 117: 205-211.

Zar, J.H. 1996. Biostatistical Analysis. $3^{\text {rd }}$ ed. New Jersey, Prentice Hall.

Zotz, G. 1999. What are backshoots good for? Seasonal changes in mineral, carbohydrate, and water content of different organs of the epiphytic orchid, Dimerandra emarginata. Annals of Botany 84: 791-798.

Zotz, G. 2000. Size dependence in the reproductive allocation of Dimerandra emarginata, an epiphytic orchid. Ecotropica 6: 95-98. 